\title{
Cervical Large Cell Neuroendocrine Carcinoma
}

National Cancer Institute

\section{Source}

National Cancer Institute. Cervical Large Cell Neuroendocrine Carcinoma. NCI Thesaurus. Code C40214.

A rare, aggressive neuroendocrine carcinoma that arises from the cervix and is characterized by the presence of malignant cells with abundant cytoplasm, large nuclei, and prominent nucleoli. 